\title{
OF MARAUDERS AND BRIGANDS: SCOPING THE THREAT OF RURAL BANDITRY IN NIGERIA'S NORTH WEST
}

\author{
Al Chukwuma Okoli ${ }^{1}$ \\ Anthony Chinedu Ugwu²
}

\section{Introduction}

Nigeria is, arguably, a country under distress. The country's woes are most evident in the torrential spate of armed violence and criminality in various parts of the country. Nothing explains this awry situation better than the apocalyptically volatile security ambience in the wider northern Nigeria. The northeastern Nigeria is still patently under the Boko Haram scourge, amidst the precarious counter-insurgency endeavors of the government (Okoli 20I7a; Zenn 20I8). The north-central area has been afflicted by herdsmen militancy, which has plunged the region into dire humanitarian crisis (Okoli and Ogayi 20I8). The northwestern region has recently been enmeshed in the rapid upsurge of rural banditry along its international frontiers as well as the forested interior.

Research on the prevailing precarious security situation of northern Nigeria has been perennial, albeit with disproportionate emphasis on the phenomena of Boko Haram insurgency and herdsmen-farmers disturbances (Olayoku 20I4; Okoli and Iortyer 20I4; Otewu 20I5; Bagu and Smith 20I7). Incidentally, while scholarship on Boko Haram and farmers-herder crises has come a full cycle, organized research on rural banditry is still at an inchoate stage of nascence. Although there exist some important scholarly works on aspects of the subject matter (Ladan 20I4; Kuna and Jibrin 20I6; Okoli and Ochim 20I6; Olaniyan and Yahaya 20I6; Olaniyan 20I8), none of these extant

I Department of Political Science, Federal University Lafia, Lafia, Nigeria. E-mail: okochuoo7@yahoo.com.

2 Department of Political Science, Federal University Lafia, Lafia, Nigeria. E-mail: chinedugwu5@gmail.com 
works could systematically and aptly account for the northwestern scenario where rural banditry has assumed the scale of a complex emergency.

This study is an attempt to explain the phenomenon of rural banditry in the northwestern Nigeria against the backdrop of the rapid upsurge of the incidence over the recent years. The northwestern Nigeria encompasses seven states namely Kano, Katsina, Kebbi, Kaduna, Zamfara, Jigawa and Sokoto. Five of these states, which are Katsina, Kaduna, Zamfara, Kebbi and Sokoto, have been mostly affected by the scourge of rural banditry. Of these five states, Katsina, Kaduna and Zamfara have been the most critical hotspots. Suffice it to note that the incidence of rural banditry is not by any means limited to northwestern Nigeria. In fact, it is also reasonably prevalent in parts of north-central region, with states like Niger, Nasarawa, Plateau and Benue as veritable hotbeds (Kuna and Jibrin 20I6; CDD 20I5a \& b).

What then is the nature of the rural banditry incidence in the northwestern Nigeria? What are its critical drivers? Moreover, how could the incidence be mitigated? These analytical posers constitute the thrust of the study. Given the scant scholarship on the subject matter, the principal purpose of the study is to undertake a sort of desk-based prima facie investigation into the phenomenon of rural banditry in the focal area with a view to stimulating further organized field-based studies on relevant aspects thereof subsequently. The remainder of the paper is thematically structured as follows: conceptualizing banditry/rural banditry; theoretical framework; perspectives on rural banditry in Nigeria; critical drivers of rural banditry in northwestern Nigeria; patterns of rural banditry in northwestern Nigeria; mitigating the rural banditry scourge; and conclusion.

\section{Conceptualizing Banditry/Rural Banditry}

Banditry refers to the incidences of armed robbery or allied violent crimes, such as kidnapping, cattle rustling, and village or market raids. It involves the use of force, or threat to that effect, to intimidate a person or a group of persons in order to rob, rape or kill (Okoli and Okpaleke 20I4). Economic or political interests motivate banditry. The former refers to banditries motivated by the imperative of material accumulation while the latter has to do with those driven by the quest to rob, to assault or to liquidate a person or a group of persons based on political or ideological considerations. Various forms of banditry have been identified in literature. Table I highlights these categories of banditry in an attempt to propose a typology of the phenomenon. 
Table 1: A Typology of Banditry

\begin{tabular}{|l|l|}
\hline Type & Typological index \\
\hline Social vs. political vs. economic & Intent or motive \\
\hline Rural vs. urban & Location \\
\hline Mercenary vs. autonomous & Agency and autonomy \\
\hline Organized vs. petty & Form and formation \\
\hline Roving vs. stationary & Operational mode \\
\hline Frontier vs. countryside & Location \\
\hline Maritime vs. coastal vs. mainland & Location \\
\hline
\end{tabular}

Source: Authors' original illustration.

As Table I indicates, banditry can be classified based on the underlying 'intent' or 'motive'. In this regard, one can talk of 'social banditry' that is generally motivated by the intent to protest social inequality and to redistribute wealth within a locality. Likewise, one could talk of other forms of banditry that are principally motivated by 'political' or 'economic' reasons. When 'location' of occurrence is the underlying index, one can speak in terms of 'rural vs. urban banditry' or 'frontier vs. countryside banditry', as the case may be. Similarly, banditry can be 'mercenary' or 'autonomous' depending on how the actor of 'agency' is played out. Mercenary banditry is perpetuated by auxiliaries or mercenaries working for a principal in a sort of principal-agent relationship, while autonomous bandits are self-motivated and personally commissioned. 'Organized banditry' thrives on a network of actors that are syndicated and coordinated while petty banditry is perpetrated by individual or group actors that are not so organized. 'Roving bandits' are more or less mobile or itinerant while stationary bandits are settled or sedentary. Lastly, 'maritime banditry' refers to offshore robbery (piracy) as compared to those that occur on the coast or mainland. Rural banditry simply means the prevalence of banditry in the rural sector. It can assume any of the characteristics highlighted above. More importantly, it thrives within the 'social ecology' of the rural sector characterized by gross governance deficits (Olaniyan and Yahaya 20I6). Prominent instances of rural banditry in Nigeria include kidnapping, armed robbery, cattle rustling and village raids. 


\section{Theoretical Framework: Routine Activity Theory}

The Routine Activities Theory (RAT) was pioneered by Cohen and Felson (I979) in an attempt "to understand patterns and upward trends of predatory criminal events in the historical context of changing economy" (Hsieh and Wang 2018, 335). The theory holds that crime is likely to occur when there is a spatial-temporal convergence of three essential elements of crime, namely a motivated offender, an attractive target, and the absence of capable guardianship (see Figure I).

According to exponents of the theory (Cohen and Felson I979; Maxfield I987; Samonas 2013), motivated offenders are individuals who are capable and willing to commit a crime while suitable targets can be a person or object that are considered by offenders as vulnerable or attractive. On the other hand, guardianship can be a person or an object that is effective in deterring offense to occur. Mere physical presence of guardianship in space and time can deter crime committal.

The Routine Activity Theory is based on some basic assumptions (Cohen and Felson I979; Garofalo I987; Maxfield I987; Felson and Cohen I980):

- Crime is likely to occur when there is a spatial-temporal convergence of three essential elements of crime, namely a motivated offender, an attractive target, and the absence of capable guardianship;

- The factors that render a particular target attractive are situational and crime-specific;

- Crime can be perpetrated by anyone who has the opportunity in terms of capability and availability of vulnerable target;

- Victims have choices on whether to be victims mainly by possibly avoiding situations where a crime can be committed against them. 
Fig. 1: An illustration of Routine Activity Theory of crime

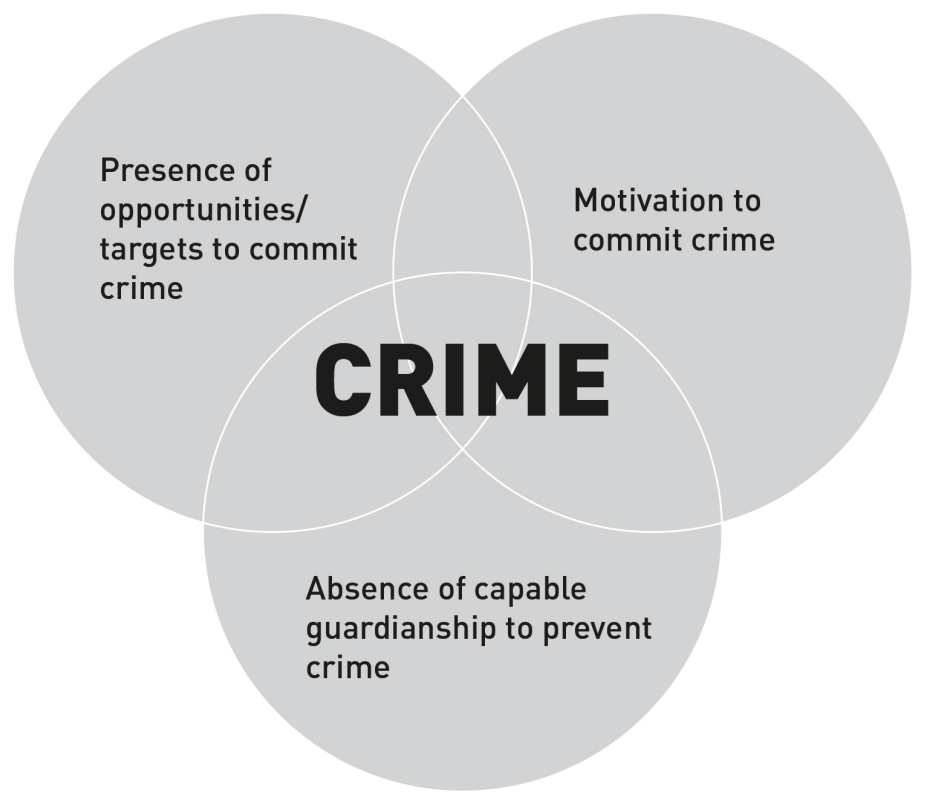

Source: Adapted from Samonas (2013). Note: The three interrelated variables depicted in Fig. 1 require physical convergence in time and space.

Applied to the purpose of the present discourse, it is to be observed that rural banditry is a crime that has been precipitated and sustained by the prevailing socio-existential environment in the rural sector characterized by a high proclivity to criminal indulgence. In the case of the focal area, northwestern Nigeria, the presence and prevalence of under-policed and unregulated hinterlands, forestlands and borderlands have provided an enormous opportunity for rural criminality. In addition, the presence of viable but vulnerable rural economy based largely on animal husbandry, crop production and informal mining, equally provides an avalanche of handy crime objects/ targets: cattle, cash, treasure, etc. In this context, the virtual absence of governmental security apparatus in most rural communities gives incentive for criminal opportunism and impunity as well (The Humanitarian 20I8). In all, the aforementioned ecology of crime brings about, not only motivation but also temptation, for criminal indulgence. Under this circumstance, criminal deterrence takes flight all forms of predatory crime prevail. This is typically 
the situation in northwestern Nigeria, where rural marauders and brigands are having a sustained field day in a criminal escapade that is threatening to overrun the entire region.

\section{Perspectives on Rural Banditry in Nigeria and Beyond: A Literature Review}

Rural banditry has to do with armed violence perpetrated by criminal opportunists and syndicates in the countryside and frontiers of countries (Okoli \& Okpaleke 20I4a). It comprises acts of armed criminality targeting at human life or property: armed robbery, kidnapping, cattle rustling and allied armed violence (Okoli \& Okpaleke 20I4b). Extant literature on the nature and incidence of rural banditry mostly perpetrated by nomads has yielded a number of thematic perspectives. Foremost among these perspectives is the narrative that situates the phenomenon as a necessary complication of farmer-herder crisis in a volatile security context characterized by the declining state's capacity to govern (Shettima \& Tar 2008; Olaniyan \& Yahaya 20I6). The second perspective characterizes the occurrence as a disguised terrorism that bears the trappings of neo-jihadism (IEP 2015; SBMI 20I5; CWI 20I6; Omilusi 20I6).

This perspective resonates with the popular local cynical anecdotes to the effect that such violence represents the calculated effort to further the islamization of the wider northern Nigeria with the Middle Belt region as the focal target. The third perspective is a narrative, which accounts for the problem from the standpoint of ethno-communal violence complicated by the faultlines of identity conflict (Blench \& Dendo 2005; Okoli \& Atelhe 20I4). There is also an emerging perspective that emphasizes the criminological undercurrents of the threat. This perspective sees the marauding nomads as aggressors who are motivated by wholly criminal intents (McGregor 20I4; Olayoku 20I4). Nascent thinking on the subject matter is tending towards a cross-cutting perspective that highlights the socio-ecological dynamics of the occurrence. This forms a part of the point of departure in this study.

Beyond the conflicting and contending perspectives above, it is pertinent to note that rural banditry is not a novelty in Nigeria. Anecdotal and scholarly accounts have it that the phenomenon predated Nigeria's emergence as a political entity. In this regard, Jaafar $(2018,2)$ opines that there were recorded instances of rural banditry in the colonial Nigeria "as far back as the I930s". Putting this claim in a sort of historical perspective, Jaafar accounts: 
In those days, wayfarers and merchants travelling along our local economic roads usually faced the threats and dangers of ambush from nondescript bandits. Armed bandits and criminals were known to be targeting goods ferried on the back of donkeys, camels and ox carts. Those bandits on our trade routes would forcefully take those goods and disappear into the bush. That is just one dimension of the problem then. In other instances, the bandits would sometimes raid farming communities and villages with the intent of willful killing and wanton destruction of property. During such raids, the bandits would destroy virtually everything in their path, including valuables, farm produce, etc. This subculture has been in existence even before the coming of colonialists to the territories of northern Nigeria $(2018,2)$.

With reference to the northwestern Nigeria, The Humanitarian (Formerly IRIN News 20I8, 8-9) avers that the region "has a long history of banditry. The first recorded case occurred somewhere between "western Hausaland" and the Niger border in I9OI, when a I2,000-strong camel train "laden with assorted grains" was attacked and 210 merchants killed". Although rural banditry is as old as Nigeria, it has nonetheless incrementally transformed overtime from its rudimentary phase, as adverted to in Jaafar's citation above, to a complex and complicated pattern of criminality (CDD 2015a; Egwu 20I6). The modern transformation of rural banditry must be understood against the backdrop of the prevailing national security dialectics in Nigeria. According to Bagu and Smith $(2017,5)$ :

Gangs of criminal, often youth from farming and herding communities and/or local bandits, take advantage of growing insecurity, fear and cyclical attacks to loot villages, engage in highway robbery, and rustle cattle for personal gain. Both farming and herding communities suffer from this criminality.

Contemporary narrative on rural banditry in Nigeria presents a pathetic humanitarian scenario. In effect, the bandits "have been robbing people on highway, rustling cattle, looting, laying siege on rural markets and killing innocent people" (CDD 20I5a, 2). Significantly, this pattern of criminality has become a leading cause of violence in Nigeria over the recent years (Azad, Crawford and Kaila 20I8). Most existing works on aspects of rural banditry in Nigeria have tended to be situating their account on the farmer-herder problematic (Shalangwa 2013; Gambari 20I8; Bashir, Azlizan and BtYusof 2018; Ahmadu 2019). Although the phenomenon bears substantively on the dialectics of farmer-herder crisis, such a perspective must be contextually 
problematized in any meaningful attempt to understand properly how the criminality obtains and prevails.

The occurrence of rural banditry is not peculiar to Nigeria. In effect, the phenomenon has been an important facet of the national security debacle in the conflict-ridden countries of Africa's Sahel and Sahara (Fatf-giaba-ga 2016; Gaye 20I8a \& b). Even beyond the shores of Africa, organized rural banditry has prevailed in places like Latin America where it is often implicated in the morass of drug war. Also in the Far East, rural banditry has been a veritable form of the so-called 'frontier criminality' (Callen, Gulzar, Rezaee and Shapiro 20I8, I). It has also been prevalent in the agrarian sector of Sweden within the continental belt of Europe (FAO 2009). The common identifier of rural banditry across these climes is its apparent opportunistic and predatory tendencies, which has made its occurrence intractable in some cases.

\section{Critical Drivers of Rural Banditry in Northwestern Nigeria}

Drivers of rural banditry in northwestern Nigeria consist in some socio-existential conditions that characterize the interior as well as the frontiers of the region. Prominent among these conditions are the scarcely governed hinterlands, forestlands and borderlines of the region. The northwestern hinterlands are marked by extremely dispersed rural settlements, separated by rangelands and farmlands that are susceptible to violent contestations (cf. Gaye 20I8a). They are also interspersed by diverse forested landscapes, some of which are dotted by wetlands, rocks and caves. Apart from being separated from each other, they are equally far separated from the centers of governance at the local and state levels.

The forestlands of the region are vast, rugged and hazardous. Most importantly, they are grossly under-policed to the point that makes them conducive to all forms of jungle criminality. In view of this, violent crimes, such as cattle rustling, have festered in such forested areas. Hence,

Nigerian authorities have recorded an increase in cattle/livestock rustling activities mainly in the north and north-west regions of Nigeria that is directly connected to BH (Boko Haram). Most attacks occur in remote villages, close to forested regions in the north-west where there is little security presence. These activities are profitable for $\mathrm{BH}$ 
but also terrorise the local population and deprive them of their food and livelihoods (FATF-GIABA-GABAC 20I6, I2).

At some points, the forests are coterminous with the multiple porous borderlines in the frontiers of the region. The porosity of the borderlines is nearly total. They are ill delineated, under-policed and thus, grossly undergoverned. The consequence of this is the free-flow of illicit activities, often facilitated by criminal state and non-state actors. These activities include smuggling, human and substance (including drugs) trafficking and a host of transnational organized crimes (cf. Gaye 20I8b).

The point being emphasized in the foregoing is that the peculiarity of the northwestern countryside and frontiers has made them liable to opportunistic exploitation by criminal gangs. The challenge has been complicated by the enormous landmasses of the region. Table 2 gives an insight in that regard.

\section{Table 2: Landmasses of selected States in Northwestern Nigeria}

\begin{tabular}{|l|l|}
\hline State & Landmass \\
\hline Kaduna State & 46,053 square kilometers \\
\hline Zamfara State & 39,762 square kilometers \\
\hline Kebbi State & 36,800 square kilometers \\
\hline Kano State & 20,131 square kilometers \\
\hline
\end{tabular}

Source: Adeniyi (2018, I3).

The above landmass distribution is significant when compared against the sizes of some states in southern Nigeria. For instance, the super -populous Lagos State has less than 4,000 square kilometers (Adeniyi 20I8). In addition to the under-governed territorial spheres highlighted above, rural banditry in northwestern Nigeria also derives impetus from the poorly regulated mining, transhumance and arms sectors. Small scale, illicit and artisanal mining in states like Zamfara have provided an enduring material incentive for bandits who occasionally plunder mining sites in order to steal gold and cash (The Humanitarian 2018). More recently, some bandits in that context have engaged in the kidnapping of foreign miners in prospect for ransomed (Personal communication, April 2019). Financial proceeds of illicit gold mining have also been fingered in the incidence of arms proliferation in the state (Adeniyi 20I8). In recognition of the untoward nexus between rural 
banditry and illicit mining, the Federal Government of Nigeria in early April, 20I9, suspended all forms of mining in Zamfara State amidst the escalating complexion of bandits' brigandage in the state and the environs.

Regarding the question of transhumance, the poorly regulated livestock enterprise in northwestern Nigeria has led to its infiltration by criminals (Olaniyan and Yahaya 2016; Okoli and Lenshie 2018). This has found expression in the intensification of cattle rustling in the region. In states such as Kaduna, Katsina, Zamfara, and Kebbi, there exists a tribe of livestock bandits who specialize in large-scale raiding of cows. While some of these cattle rustling gangs are affiliated with local and transnational syndicates, a number of them act as mercenaries to Boko Haram (Okoli 20I7b). To be sure, cattle rustling constitute a veritable source of Boko Haram's funding. The destruction of the rural economy in northeastern Nigeria by insurgency and counter-insurgency operations has limited the prospect of cattle rustling in the area. Consequently, the insurgents have taken to north-central and northwestern regions as alternative fields for cattle rustling. This partly but vitally explains the spate of cattle rustling in the regions over the years.

Our discourse on the drivers of rural banditry in northwestern Nigeria will not be complete without a mention of the issue of arms proliferation. There has been an incremental influx of Small Arms and Light Weapons (SALWs) into Nigeria from the Sahel since the fall of Ghadaffi's regime in Libya (cf. Gaye, 2018). These arms and weapons end up in the hands of terrorists, militants and bandits, who use them to terrorize individuals and communities. In September 20I8, military troops in joint operations with personnel of the Department of State Service (DSS) arrested two suspected illicit arms dealers along Funtua-Gusau road with I,479 rounds of $7.62 \mathrm{~mm}$ (special) ammunition, on their way to deliver the weapons to armed bandits (Adeniyi 20I8, 6). Incidents such as this have been sporadic in the various states of northwestern Nigeria where rural banditry has become the order of the day.

From the foregoing, it is evident that the incidence of rural banditry in northwestern Nigeria is symptomatic of a combination of factors. As indicted previously, there is an avalanche of 'ungoverned', 'under-governed' and 'ungovernable' spheres within the territorial domain of the focal area. However, beyond this narrative is the salient question of state's functionality in relation to security and territorial governance (Okoli and Ochim 20I6; Azad, Crawford, and Kaila 20I8). The Nigerian State has increasingly grossly demonstrated a pathological incapacity to govern. The government at all levels has exhibited a woeful lethargy in dealing with national security emergencies. 
Essentially, therefore, while the menace of rural banditry subsists, the government has persistently failed to muster requisite political will and commitment to tackle the situation. As Jaafar $(2019,3)$ would like to put it "What we are seeing today is not something that is historically unprecedented. What is new, however, is the incapacity, indifference or unwillingness of the Nigerian state to put the insurgence of rural banditry under its effective control". And The Humanitarian (9-10) succinctly adds from the case of Zamfara:

The tragedy for modern-day Zamfara is that more than a century on, there are still ungoverned spaces where the state is incapable of stamping its authority. Control is so weak in some regions that bandits can come into rural towns, typically three-up on a motorbike, unchecked. In some areas they lay down the law and become the local authority.

The Zamfara case is uniquely perplexing in that bandits in some areas of the State have gone not only sedentary but also territorial. They have founded underworld fiefdoms in the jungles where criminal impunity prevails amidst the ruthless 'authority' of the kingpin-bandits. The story of Buharin Daji - and his cohorts of criminal overlords - speaks volume of this arcane deterioration of the rural banditry infamy in the state (The Humanitarian 20I8). Of all the states in the Federation of Nigeria, Zamfara has become most notorious for cattle rustling and allied jungle criminalities. Table 3 sheds light on this fact from the standpoint of cattle rustling incidence. 
Table 3: Estimated number of livestock rustled in the Zamfara State in 2016

\begin{tabular}{|l|l|}
\hline Area & Number of Animals \\
\hline Badarawa & Over 200 \\
\hline Bagega & Over 4.500 \\
\hline Dorayi & Over 2.500 \\
\hline Filinga & Over 5.000 \\
\hline Gidan Kaso & 1455 \\
\hline Guru & 270 \\
\hline Jangeme & Over 600 \\
\hline Kizara & Over 4000 \\
\hline Lilo & 90 \\
\hline Lingyado & Over 2100 \\
\hline Madaba & 106 \\
\hline Nasarawa Godal & Over 1000 \\
\hline Nasarawa Mai Layi & 500 \\
\hline Rukudawa & 250 \\
\hline Shigama and Kwokeya & 1020 \\
\hline Tsabre & Over 3500 \\
\hline Tungar Baushe & 1110 \\
\hline Unguwar Galadima & 850 \\
\hline Yar gada & 230 \\
\hline Danta & \\
\hline
\end{tabular}

Fonte: MACBAN (20I6), citado em RUFAI (20I6).

\section{Patterns of Rural Banditry in North West Nigeria}

Four patterns of rural banditry are discussed in this study, namely village raids, highway robbery, kidnapping and cattle rustling. Village raids are the invasion and plundering of rural communities, especially at nights. These often take the form of scorch-earth attacks that leave affected commu- 
nities in utter desolation in the aftermath of an incident. Village raids can be uni-episodic or coordinated. The former occurs when a single community is attacked while the latter happens when the attack occurs simultaneously on a number of adjacent communities within a locality. The principal purpose of village raids is material plundering. In effect, in most instances, household, farmlands, shops and markets are targets of looting. It is pertinent to note, however, that some of the attacks have been merely reprisals, designed to show down on communities, which have hitherto challenged or resisted the bandits' onslaught through organized vigilantism (Okoli 20I7a).

Village raids have been a common feature of the rural banditry escapade in northwestern Nigeria. Their occurrence has been perennial in the hinterlands of Zamfara and Kaduna States (see Table 3). According to Amnesty International (2018: 22):

Several villages in Birnin-Gwari LGA of Kaduna State continue to face security challenges similar to those in Zamfara State. Their situation is even more volatile, due to the proximity of the LGA to Zamfara State. The forests that cut across the two states (Kaduna and Zamfara states), made the residents vulnerable to repeated abductions.

In view of the lethality of such attacks, many lives and property have been lost in every incident. This is in addition to massive population displacements and allied humanitarian complications that are also engendered (Bagu and Smith 20I7).

Highway robbery is another critical dimension to the rural banditry phenomenon in the North East. This obtains mainly in the fashion of waylaying of commuters on the various expressways in the region (see Table 3). Abuja-Kaduna-Zaria highway has been particularly notorious for highway robberies. The incidence has also been alarming on the Kaduna-BirninGwari-Zamfara-Funtua and Zaria-Funtua-Katsina highways. The highway robbers operate with wartime arms and commando-like brutality. In most incidents, they kill and maim people in their scores. The rampant cases of armed robbery on the Abuja-Kaduna expressway have forced some regular travelers on that route to defect to the use of rail services to commute to and from their destinations in order to safeguard themselves.

Closely associated with highway robbery is the menace of kidnapping. This has been incessant in states like Kaduna, Katsina and Zamfara (See Table 3). Kidnapping is a predatory criminality driven by quest for ransom. Victims of the crime are often those perceived by the perpetrators as possessing some Kidnap Ransom Value (KRV) based on their socio-economic 
background (Okoli and Agada 20I4). Patterns of kidnapping in northwestern Nigeria include highway-armed abduction whereby travelers are ambushed and abducted by bandits and then taken to a hideout in the forest where their relatives or associates are contacted for ransom payment. This form of kidnapping is common on the Abuja-Kaduna highway. Another important game of kidnapping prevalent in northwestern Nigeria is mass abduction. This is an instance where a group of persons is taken hostage by bandits who are prospecting for ransom. A case in point is the abduction of twenty caregivers in Jibya Local Government Area of Katsina State on December 23, 2018 (see Table 3).

The incidence of kidnapping for ransom in northwestern Nigeria has been disturbing. Between December, 20I8, and March, 2019, Zamfara State alone recorded many incidents of kidnapping involving 227 victims (Gusua 20I9, I). The crime is also prevalent in Kaduna and Katsina States where scores of persons have been kidnapped over the recent years. In Katsina State, kidnapping is most rampant in the rural communities surrounding the notorious Rugu forest, which has been a veritable hideout for bandits (cf. Ladan 20I4).

The most patent dimension of rural banditry in northwestern Nigeria is cattle rustling. This is a form of organized cattle theft driven by allied accumulative or profiteering tendencies. Of this, Bagu and Smith $(2017,5)$ aptly opine that "in North West Nigeria, criminal gangs are reportedly engaging in organized rural banditry to profit off livestock theft and trade... ". Cattle rustling is intractable in northwest Nigeria because it fits organically into the peculiar political economy of the region wherein mobile pastoralism is an abiding practice (CDD 20I5b). This political economy is situated within the rural agrarian sector that is hardly regulated. However, mobile pastoralism in the area has been associated with systemic contradictions, one of which is the emergence of a tribe of criminal nomads who indulge in all forms of opportunistic rural criminality (Okoli and Lenshie 20I8). This explains, to a reasonable extent, the prevalence and apparent intractability of cattle rustling in parts of northwestern Nigeria. Table 3 also highlights select instances of cattle rustling in the region over the recent years in serial roll four. 
Table 4: Patterns of Rural Banditry in Northwestern Nigeria

\begin{tabular}{|c|c|}
\hline Form of Banditry & Selected Instances/Indicators \\
\hline Kidnapping & $\begin{array}{l}\text { A catholic priest was kidnapped in Ankuwa, Kachia Local } \\
\text { Government of Kaduna State on March 25, } 2019 . \\
\text { Twin sisters were kidnapped in Daura village, Zurmi Local } \\
\text { Government Area of Zamfara State on October 21, } 2018 . \\
\text { A North Korean Medical Doctor was kidnapped Tsafe Local } \\
\text { Government Area in Zamfara State on March 25, } 2019 . \\
20 \text { caregivers were kidnapped in Jibya Local Government } \\
\text { Area of Katsina State on December 23, } 2018 .\end{array}$ \\
\hline Village Raids & $\begin{array}{l}\text { Motorcycle-riding gunmen attacked Kwara Village in } \\
\text { Shinkafi District of Zamfara State Killing about } 30 \text { persons } \\
\text { on March 5, } 2019 . \\
\text { Gunmen on motorcycles stormed Magami village in Mara- } \\
\text { dun District of Zamfara State, killing and maiming several } \\
\text { persons on December 23, } 2018 . \\
\text { Scores of suspected bandits raided Gwaska village in Bir- } \\
\text { nin-Gwari Local Government Area of Kaduna State, killing } \\
45 \text { persons on May 6, } 2018 . \\
\text { On April 28, 2018, } 40 \text { miners were killed at Janruwa Village } \\
\text { and a week later (May } 5^{\text {th }), ~} 71 \text { people were killed in Gwaska } \\
\text { (these are villages in Birnin-Gwari Local Government Area } \\
\text { of Kaduna State). }\end{array}$ \\
\hline Highway Robbery & $\begin{array}{l}\text { Travelers were attacked by suspected bandits near Gidam } \\
\text { Busa along Kaduna-Abuja expressway on July 22, } 2018 . \\
\text { Gunmen attacked travelers at Mashaya Mariki, along Sokoto } \\
\text {-Tureta road on October 9, } 2018 . \\
\text { Thers have been perennial incidents on Kadun-Zaria-Fun- } \\
\text { tua-Katsina highway until date. }\end{array}$ \\
\hline Cattle Rustling & $\begin{array}{l}\text { In 2013, over 1,000 cows were stolen by armed-to-the- } \\
\text { teeth rustlers from a farm belonging to the former Vice Pre- } \\
\text { sident, Namadi Sambo, in the Birin-Gwari area of Kaduna } \\
\text { State. } \\
\text { Zamfara State accounted for } 446 \text { of the } 470 \text { incidents of } \\
\text { cattle rustling fatalities recorded in four affected states } \\
\text { of northern Nigeria: Kano, Katsina, Niger and Zamfara in } \\
2015 / 2016 \text {. } \\
\text { There is a thriving international cattle market in Jigawa } \\
\text { State patronized by Boko Haram insurgents. }\end{array}$ \\
\hline
\end{tabular}

Source: Author's compilation. 


\section{Mitigating the Scourge of Rural Banditry}

The menace of rural banditry in northwestern Nigeria is a phenomenal threat with asymmetric proportions. In its current manifestation, it has rivaled Boko Haram insurgency in terms of lethality and humanitarian consequences. Yet, its trajectory adumbrates a scenario that is ominously snowballing into a complex emergency surpassing the Boko Haram onslaught. The tragedy of the situation is that the criminality obtains an organic socio-existential context that makes it not only burgeoning but also pervasive. Already, the occurrence has pervaded most states of the northwestern region, with huge collateral ripples in the north-central axis.

Apart from the attendant deaths and material destruction, the crisis has engendered frosty inter-group relations in the affected areas. A case in point is the Habe-Fulde (Hausa-Fulani) tension in Zamfara and environs (Bagu and Smith 20I7; Amnesty International 20I8). The crisis has also led to declining rural productivity in many parts of the focal region, leading to aggravated rural poverty and destitution. So far, the response of the government towards addressing the crisis has been overly situational and combatant. The military-style response has consisted of strategic patrol and surveillance, armed reconnaissance, as well as coordinated air raids at the various flashpoints. Rather than mitigating the situation, the military operations have significantly led to the dispersal of the criminal gangs in multiple locations within the North West. Consequently, states such as Sokoto and Kebbi, which were hitherto scantly affected by the scourge, have overtime been inundated by incidents.

While it is advisable to continue with the military campaign against the bandits, the most imperative for the government at all levels is to devise an effective means of subverting the prevailing social ecology of rural banditry in the focal region. This would include, among other things, a conscientious effort at policing the gamut of forested landscapes of the region, regulation of trans-border activities at the frontiers, harnessing the transhumance and mining sectors of the region and controlling the spate of arms proliferation in the area. In other words, there is a need to undo the extant drivers and contours of rural banditry in the North West through an adroit security strategy that prioritizes proper territorial governance. In addition, this strategy must recognize and prioritize the need to systematically unravel and negate the entirety of socio-structural and existential factors that drive and sustain the occurrence. 


\section{Conclusions}

Nigeria national security ambience has been quite tense and volatile over the years. While the North East is still under the siege of Boko Haram, the North West is steadily sliding into the morass of rural banditry. Just like Boko Haram insurgency, rural banditry in northwestern Nigeria has metamorphosed from a sporadic onset to a rapid upsurge in the recent years. Again, quite like the insurgents, the bandits have become not only stationary but also sedentary in the frontiers and hinterlands of the North West. The consequence has been massive plundering and carnage, which has plunged the region into a sort of humanitarian eschatology.

This study sought to explore the threat of rural banditry in northwestern Nigeria against the rising incidence of the menace in that context. The study observed that rural banditry in the area has festered under a socio-existential condition characterized by spatio-temporal governance deficits. The existence of scarcely governed hinterlands, borderlines and forestlands, as well as poorly regulated mining and transhumance sectors, has created an enduring atmosphere of criminal opportunism in the focal area. The situation has been complicated by the incidence of arms proliferation arising from the under-controlled local and transnational arms markets. Consequently, there has been a high incidence of village raids, highway robberies, kidnapping and cattle rustling in the area with attendant human security implications. Mitigating this challenge has been quite herculean. Nonetheless, the way forward lays in a systematic approach capable of devitalizing the gamut of socio-existential factors that underlie it. This would entail a conscious and conscientious effort at undoing the totality of the socio-existential conditions that tend to precipitate it.

\section{References}

Adeniyi, O. 20I8. "Beyond the banditry in Zamfara". Available online at: $\quad$ https://www.thisdaylive.com/index.php/2018/04/05/beyond-the-banditry-in-zamfara/ (accessed April I6, 2019).

Ahmad, A. J. 20I9. "Insight into the dynamics and menace of cattle rustling: A case study of Lake Chad Area in northern Nigeria". World Journal of Social Science Research, 6(I), pp. I8-33. 
Amnesty International [AI]. 2018. Harvest of deaths: Three years of bloody clashes between herders and farmers in Nigeria. Abuja: Amnesty International.

Azad, A., Crawford, E. and Kaila, H. 2018. Conflict and violence in Nigeria: Results from the North East, North Central and South South. Abuja: National Bureau of Statistics.

Bagu, C. and Smith, K. 20I7. Past is prologue: Criminality and reprisal attacks in Nigeria's Middle Belt, Washington, DC: Search for Common Ground.

Bashir, A.M., Azlizan, T. and BtYusof, R. 20I8. "Cattle rustling in Kaduna State, Nigeria: An assessment of the existing preventive approaches". International Journal of Management Research and Review, 8(9), pp. 20-29.

Blench, R. \& Dendo, M. 2005. Natural resource conflicts in North-Central Nigeria: A handbook and case studies. London: DFID.

Callen, M., Gulzar, S., Rezaee, A. and Shapiro, J.N. 2018. "Choosing ungoverned pace: Pakistan's Frontier Crimes Regulation”. Draft paper, Harvard Kennedy School of Government. Email: michael callen@ hks.harvard.edu.

Centre for Democracy and Development [CDD]. 20I5a. Policy brief: Addressing rural banditry in northern Nigeria. Abuja: Centre for Democracy and Development, Nigeria.

Centre for Democracy and Development [CDD]. 20I5b. Policy brief: The political economy of rural banditry in contemporary Nigeria. Abuja: Centre for Democracy and Development, Nigeria.

Century Wilberforce Initiative [CWI]. 2016. Nigeria: Fractured and forgotten: Discrimination and violence along religious faultiness. A publication of $2 \mathrm{I}^{\text {st }}$ Century Wilberforce Initiative $<$ www.2 Iwilberforce.org/ news-room/.../2Icwi...nigeria-fractured-and-forgotten.../I05/> (accessed October 20, 20I6).

Cohen, L. E.; Felson, M. I979. "Social change and crime rate trends: A Routine Activity Approach”. American Sociological Review. 44 (4), pp. 588-608; doi: 10.2307/2094589. JSTOR 2094589.

Egwu, S. 20i6. "The political economy of rural banditry in Contemporary Nigeria”. In M.J. Kuna and J. Ibrahim, eds, Rural Banditry and Conflicts in Northern Nigeria, Abuja: Centre for Democracy and Development. 
Fatf-giaba-ga. 20I6. Terrorism financing in West Africa and Central Africa, Paris: FATF, October, available < www.fatf-gafi.org/puplications/ methodsondtrends/documents/ terrorist-financing-west-centra-africa.html> (accessed i9 July 20I7).

Felson, M and Cohen, L. E. I980. "Human ecology and crime: A routine activity approach”. Human Ecology. 8 (4), pp. 389-406. doi: Io.I007/ BFoI56IOOI.

Food and Agricultural Organization [FAO]. 2009. "Roving bandits in modern fisheries”. Swedish FAO Committee Publication Series, Number 5. Swedish Ministry of Agriculture.

Gambari, I. A. 20I8. "Violent conflicts, conflict resolution and peacebuilding: Global best practices and new perspectives on farmer-herder clashes in Nigeria". Paper presented at a public lecture at the University of Uyo, Nigeria, on August 24, 2018.

Garofalo, J. 1987. Reassessing the lifestyle model of criminal victimization. Beverly Hills, California: Sage.

Gaye, S.B. 2018a. Conflicts between farmers and herders against a backdrop of asymmetric threats in Mali and Burkina Faso. Dakar: Friedrich Ebert Stiftung.

Gaye, S.B. 2018 b. Connections between jihadists groups and smuggling and illegal trafficking rings in the Sahel. Dakar: Friedrich Ebert Stiftung.

Gusau, S. 2019." ZEMA: 227 Zamfara residents kidnapped since December 2018". Available online at < https://www.dailytrust.com.ng/zema-227-zamfara-residents-kidnapped-since-december-20I8.html> (assessed April i6, 2019).

Hsieh, M. and Wang, S. K. 20I8. "Routine activities in a virtual space: A Taiwanese case of an ATM hacking spree". International Journal of Cyber Criminology, I2(I), pp.333-352.

Institution for Economics and Peace [IEP]. 20I5. Global Terrorism Index, 2015. Publication of Institution for Economics and Peace; economicsandpeace.org/wp-content/uploads/.../Global-Terrorism-Index-2016.2.pdf (accessed November 23, 20I7).

Jaafar, J. 20I8. "Rural banditry, urban violence and the rise of oligarchy by Professor Abubakar Liman". Available online at <https://dailynigerian.com/rural-banditry-urban-violence-and-the-rise-of-oligarchyby-prof-abubakar-liman/> (accessed April I6, 20I9).

Kuna, M.J. and Ibrahim, J., eds. 20I6. Rural banditry and conflicts in Northern Nigeria, Abuja: Centre for Democracy and Development. 
Ladan, S. 20I4. "Forests and Forest Reserves as security threats in northern Nigeria”. European Scientific Journal, Io (35), pp.I20-I42.

Maxfield, M. G. I987. "Lifestyle and routine activity theories of crime: Empirical studies of victimization, delinquency, and offender decision-making". Journal of Quantitative Criminology. 3 (4) pp. 275282. doi:I0.1007/BFoIo6683I.

McGregor, A. 2014. “Connection between Boko Haram and Nigeria's Fulani herdsmen could spark a Nigerian civil war". Terrorism Monitor, I2 (го), pp. 8-ıо.

Misereor. 20I8. Towards a peaceful coexistence between herders and farmers in Nigeria: Conclusions drawn from field. Abuja: Catholic Secretariat of Nigeria.

Okoli, A. C. \& Lenshie, E. N. 2018. "Nigeria: Nomadic migrancy and rural violence in Nigeria". Conflict Studies Quarterly, 25, pp.68-85.

Okoli, A. C. 20I7a. "Nigeria: Volunteer vigilantism and counter-insurgency in the North- East". Conflict Studies Quarterly, 20, pp. 34-55.

Okoli, A.C \& Agada, A.T. 20I4. "Kidnapping and national security in Nigeria". Research on Humanities and Social Science, 4(6), pp. I37-I46.

Okoli, A.C. \& Atelhe, G. 20I4. "Nomads against natives: A political ecology of farmer/herder conflicts in Nasarawa State, Nigeria". American International Journal of Contemporary Research, 4(2), pp.76-88.

Okoli, A.C. \& Iortyer, P. 20I4. "Terrorism and humanization crisis in Nigeria: insights from the Boko Haram insurgency”. Global Journal of human social science (F: Political Science) I4(I:I.O), pp. 39-50.

Okoli, A.C. \& Ochim, F. 20I6. "Forestlands and National Security in Nigeria: A Threat-Import Analysis". IIARD International Journal of Political and Administrative Studies, 2(2), pp. 43-53.

Okoli, A.C. \& Ogayi, C.O. 20I8. "Herdsmen militancy and humanitarian crisis in Nigeria: A theoretical briefing", African Security Review, 27:2, pp.I29-I43; doi: 10.1080/10246029.2018.I499545.

Okoli, A.C. 20I7b. "Cows, cash and terror: How cattle rustling proceeds fuel Boko Haram insurgency in Nigeria”. Paper presented at International Policy Dialogue Conference on money, security, and democratic governance in Africa, organized by CODESRIA and UNOWAS on October Ith to $23^{\text {rd }}, 20 I 7$ at Blu Radisson Hotel, Bamako, Mali. 
Okoli, A.C. and Okpaleke, F.N. 20I4a. "Banditry and crisis of public safety in Nigeria: issues in national security strategics", European Scientific Journal io(4), pp. 350-62.

Okoli, A.C. and Okpaleke, F.N. 20I4b. "Cattle rustling and dialectics of security in northern Nigeria". International Journal of Liberal Arts and Social Sciences 2(3): I09-I7.

Olaniyan, A. 20I8. "Foliage and violence: Interrogating forests as a security threat in Nigeria". African Security Review, 27 (I), pp. I-20.

Olaniyan, A. \& Yahaya, A. 20I6. "Cows, bandits and violent conflicts: Understanding cattle rustling in Northern Nigeria". African Spectrum, 3, pp. 93-105.

Olayoku, P.A. 20I4. "Trends and Patterns of Cattle Grazing and Rural Violence in Nigeria (2006-200I4)". IFRA- Nigeria e-papers, Number 34.

Omilusi, M. O. 20I6. "Revolving terrorists or innocuous cattle grazers? Between herdsmen's economic survival and community annihilation in Nigeria". Cultural relations Quarterly Review, summer, pp. 48-76.

Otegwu, I.O. 2015. "Insurgency in West Africans: A critical assessment of federal government response to the Boko Haram insurgency in Nigeria (2009-2013)". Ph.D Thesis submitted to the Post-graduate school, Ahmadu Bello University, Zaria (September).

Rufai, M.A.. 20I6. "The role of vigilante groups in the fight against rural banditry in Zamfara State, North-Western Nigeria". Draft paper, Department of History, Usmanu Danfodiyo University, Sokoto (UDUS), Nigeria.

Samonas, S. 20I3. "Insider fraud and Routine Activity Theory: A thought experiment". Paper originally presented at I2th Annual Security Conference, II April 2013, Las Vegas, Nevada. Available at: http:// eprints.lse.ac.uk/50344.

SB Morgan Intelligence [SBMI]. 20I5. Terror in the food basket: A look into the violence in North-Central Nigeria. A publication of SB Morgan Intelligence <sbmintel.com/wp-content/uploads/.../20I5Io_Terrorin-the-Food-Basket_summary.pd...> (accessed November 23, 20I7).

Shalangwa, M.W. 2013. "The nature and consequences of armed banditry in border communities of Adamawa State, Nigeria". M.Sc. thesis submitted to the School of Post-Graduate Studies, Ahmadu Bello University, Zaria, Nigeria. 
Shettima, A.G. \& Tar, U.A. 2008. "Farmer-pastoralist conflicts in West Africa: Exploring the causes and consequences". Information, Society and Justice, I.2, pp. I63-184.

The Humanitarian (September, 2018). “Zamfara: Nigeria’s wild northwest”. $<$ http://www.thenewhumanitarian.org/news-feature/2018/09/13/ zamfara-nigeria-s-wild-northwest> (accessed April 20, 2019).

Zenn, J. 20I8. "The terrorist calculus in kidnapping girls in Nigeria: Cases from Chibok and Dapchi”. CTC Sentinel, II(3), pp. I-8.

\section{ABSTRACT}

This study explores the phenomenon of rural banditry in Nigeria's northwestern region against the backdrop of its rising incidence over the recent years. By means of a qualitative analysis of secondary data, aided by the Routine Activity Theory (RAT), the study posits that rural banditry in the North West Nigeria thrives within a socio-existential context characterized by governance deficits, which has created an abiding pretext for criminal opportunism and impunity. The study identifies the scarcely governed borderlines, hinterlands and forestlands as well as the poorly regulated mining, transhumance and arms sectors in the region, as the critical drivers of the rural banditry scourge. With reference to the incidences of village raids, highway robberies, kidnapping and cattle rustling, the study situates the palpable threat of rural banditry in the focal area, noting that mitigating the scourge requires a systematic approach capable of devitalizing the gamut of socio-existential factors that underlie and precipitate it.

\section{KEYWORDS}

Bandits; Cattle rustling; Kidnapping; Highway robbery; Village raids; North West Nigeria. 